\title{
Flotation chemistry features in bastnaesite flotation with potassium lauryl phosphate
}

\author{
Weiping Liu ${ }^{1,2}$, Xuming Wang ${ }^{2}$,Zhixing Wang ${ }^{1}$, J.D. Miller ${ }^{2 *}$ \\ 1.School of Metallurgy and Environment, Central South University \\ Changsha, Hunan Province, 410083, China \\ 2.Department of Metallurgical Engineering, College of Mines and Earth Sciences \\ University of Utah, Salt Lake City, UT 84112, USA
}

\begin{abstract}
Bastnaesite is a major mineral resource of importance in the production of rare earth materials. Present flotation practice uses a reagent schedule which typically includes fatty acid or hydroxamic acid as collector. In this research it was found that potassium lauryl phosphate is an appropriate collector for bastnaesite flotation. Results from contact angle and micro-flotation experiments for bastnaesite are reported using potassium lauryl phosphate as collector. Better bastnaesite flotation is achieved at a low level of lauryl phosphate addition when compared to the use of octyl hydroxamate as collector. Initial evaluation suggests that potassium lauryl phosphate should be a promising collector for bastnaesite flotation.
\end{abstract}

Key words: lauryl phosphate; bastnaesite; rare earth; micro-flotation

\footnotetext{
* Corresponding author: J.D. Miller. E-mail address: Jan.Miller@ utah.edu (J.D. Miller). Tel.: +1 (801) 5815160 $1 / 25$
} 


\section{Introduction}

The rare earth fluorocarbonate mineral, bastnaesite $(\mathrm{Ce}, \mathrm{La}) \mathrm{FCO}_{3}$, is a semi-soluble salt mineral, which minerals are characterized by their ionic bonding and are distinguished from soluble salt minerals by their limited solubility in water. The mineral bastnaesite consists mainly of the cerium subgroup or the lighter rare earths elements (Bulatovic, 2010). Two major deposits of bastnaesite are the Mountain Pass deposit in California, USA, and the Boyan Obo deposit in Mongolia, China (Jordens et al., 2013; Houot et al., 1991).

Industrial flotation of the Mountain Pass ore is practiced with fatty acids as collectors, with soda ash and lignin sulfonate as depressants and with elevated pulp temperatures in order to achieve acceptable selectivity (Pradip, 1981). Phosphoric esters, as well as fatty acids, have been tested as collectors for the Bayan Obo ore (Houot, et al., 1991).

The problem with the use of fatty acid collectors is the low level of selectivity in bastnaesite flotation (Fuerstenau and Pradip, 1988). Alkyl hydroxamate, potassium octyl hydroxamate, as well as modified octyl hydroxamic acid (MOHA), are promising collectors, because of the functional group's specificity for rare-earth cations when compared to the hydroxamate's stability with alkaline-earth cations (Fuerstenau and Pradip, 1988; Nagaraj, 1988). In this way, the hydroxamates exhibit a better 
selectivity than fatty acids in the flotation of bastnaesite at concentrations $>1 \times 10^{-4} \mathrm{M}$ (Fuerstenau and Pradip, 1988; Pradip and Fuerstenau, 1985; Ren et al., 1997). The surface chemistry features of the octyl hydroxamate / bastnaesite system have been researched recently at lower concentrations $\leq 1 \times 10^{-4} \mathrm{M}$ (Zhang et al., 2014). However, the application of the hydroxamate collector is limited by its cost. Such selective collectors are generally more expensive to produce than traditional fatty acid collectors; the fatty acid is $\$ 0.70-1.00 / \mathrm{lb}$ compared with $\$ 4.00-6.00 / 1 b$ for hydroxamic acid.

Consequently research efforts are appropriate to identify economic and selective collectors for the flotation of rare earth minerals, especially bastnaesite. In addition to fatty acid and hydroxamic acid, phosphorous-containing anionic collectors for bastnaesite include phosphonate collectors (Zhang and Jian, 1981; Zhang et al., 1982) and phosphate collectors (Chehreh Chelgani et al., 2013; Jordens et al., 2014; Srinivas et al., 2004; Zhou and Luo, 1989, 1990). Some researchers have reported that alkyl phosphates have better performance as collectors for bastnaesite than alkyl phosphonates (Zhou and Luo, 1989, 1990).

However, the fundamental surface chemistry associated with alkyl phosphate adsorption at the bastnaesite surface is still unknown. Therefore, a preliminary evaluation of the surface chemistry features of potassium lauryl phosphate flotation of bastnaesite has been conducted. 
The results for micro-flotation of bastnaesite with potassium lauryl phosphate and octyl hydroxamic acid are compared. The discussion includes wetting characteristics, surface tension results, micro-flotation results and the results from electrophoretic measurements.

\section{Materials and methods}

\subsection{Materials}

Cola®Fax PME from Colonial Chemical Incorporated Company was purchased as a 30wt.\% solution of potassium lauryl phosphate $\left(\mathrm{C}_{12} \mathrm{H}_{26} \mathrm{O}_{4} \mathrm{PK}\right)$, and the price was $\$ 0.98 / \mathrm{lb}$. Research grade octyl hydroxamic acid $\left(\mathrm{CH}_{3}\left(\mathrm{CH}_{2}\right)_{6} \mathrm{CONHOH}\right)$ of high purity was provided by Cytec and used for micro-flotation experiments.

The bastnaesite sample was from the Zagi Mountains in Pakistan. For contact angle measurements, the bastnaesite surface was polished and cleaned by rinsing with acetone, methanol and copious amounts of deionized (DI) water, followed by blow drying with high-purity nitrogen. The samples were then treated with plasma and again dried with high-purity nitrogen gas. Then the contact angle measurements were made. For micro-flotation experiments the bastnaesite was ground with a mortar and pestle. The ground sample was washed, dried and sized. After sizing, the $100 \times 200$ mesh size class was taken for flotation. 
All other glassware was cleaned by rinsing with acetone, methanol and copious amounts of DI water and dried by high-purity nitrogen gas. De-ionized water was obtained from a Milli-Q system (Billerica, MA). The resistivity of the water was above $18 \mathrm{M} \Omega$ in all experiments.

\subsection{Turbidity and $\mathrm{pK}_{\mathrm{a}}$ measurements}

In order to assure that no precipitation occurred within the potassium lauryl phosphate solution, the turbidity of aqueous solutions of potassium lauryl phosphate was measured as a function of concentration using a DR/850 Portable Colorimeter (Hach Company). The instrument was adjusted to measure turbidity by using the "program 95 " of the instrument. The meter was zeroed with $10 \mathrm{ml}$ of deionised water (blank) and the turbidity of collector solutions read directly from the instrument. The turbidity of de-ionized water is 0 FAU (Formazin Attenuation Unit). If the turbidity of collector solution is 0 FAU (Formazin Attenuation Unit), the collector solution should be transparent. If precipitation occurs, then the turbidity value will increase. More applications and details of turbidity measurement can be found in the literature (Goncharuk et al., 2009; Onweluzo and Akuagbazie, 2010).

The $\mathrm{pK}_{\mathrm{a}}$ was measured by the potentiometric titration method using a $\mathrm{pH}$ electrode to monitor the course of titration. The $\mathrm{pK}_{\mathrm{a}}$ value was 
calculated from the change in shape of the titration curve compared with that of a blank titration without lauryl phosphate present. For an excellent introduction to the method for determination of $\mathrm{pK}_{\mathrm{a}}$, interested readers should consult Babić et al. (2007) and Reijenga et al. (2013).

\subsection{Contact angle measurements}

Contact angles were measured with a Rame-Hart goniometer (Rame-Hart, Succasunna, NJ) using the captive bubble technique. The measurement of an intermediate contact angle was accomplished by the release of an air bubble from the needle tip after formation with a syringe, the bubble was then captured beneath the bastnaesite surface, followed by film rupture and bubble attachment. The equilibrium contact angle was measured for all cases of attachment. For each specific measurement, at least five bubbles were generated and measured at different locations on the surface. The reported values are average values from these measurements. The maximum experimental variation in contact angle was found to be $\pm 1^{\circ}$ (Drelich et al., 1996b; Lam et al., 2001; Lam et al., 2002). Readers interested in learning more about the contact angle measurement technique and the nature of hydrophobic and hydrophilic surfaces should consult Drelich et al. (1996a) and Drelich et al. (2011). 


\subsection{Electrophoresis Measurements}

Zeta potential is the electric potential in the interfacial double layer at the slipping plane and can be affected by $\mathrm{pH}$ and solution composition (Schwer and Kenndler, 1991). It is widely used for quantification of the magnitude of the electrical charge. In the present study, bastnaesite samples from Zagi Mountains, Pakistan were dry ground to $-45 \mu \mathrm{m}$. Before measurement, bastnaesite suspensions of $0.1 \%$ were prepared and centrifuged for 10 minutes. Zeta potentials of bastnaesite (Zagi Mountain, Pakistan) were measured using a ZetaPALS instrument, Brockhaven Instruments Corporation, measurements from which are based on the doppler effect combined with a phase shift of the reflected light. Bastnaesite particle mobilities were measured at different $\mathrm{pH}$ values and then converted to zeta-potentials $(\xi)$ using Smoluchowski's model as follows:

$$
U=\frac{\varepsilon \xi}{4 \pi \eta} E_{\infty}
$$

where $\mathrm{U}$ is the particle mobility, $\mathrm{E}_{\infty}$ is the applied electric field, and $\varepsilon$ and $\eta$ are the dielectric constant and viscosity of the solvent. Readers interested in learning more about the zeta potential measurement technique should consult reviews by (Greenwood, 2003) and (Hunter, 1998). 


\subsection{Micro-flotation tests}

The micro-flotation tests for bastnaesite with lauryl phosphate (Cola®Fax PME) and hydroxamic acid as collectors were performed using a $112 \mathrm{ml}$ column cell with a porous sintered glass bottom for gas dispersion and a magnetic stirrer. In each test, the bastnaesite sample $(100 \times 200 \mathrm{mesh})$ of $1 \mathrm{~g}$ was added to the collector solution and then conditioned for 5 min by magnetic stirring. After that the sample, together with solution, was transferred to the flotation cell. The flotation tests were conducted for 2 min using nitrogen at a flow rate of $50 \mathrm{ml} / \mathrm{min}$. Each micro-flotation test was repeated three times, and the mean value of recovery was reported. Further information about the micro-flotation cell design and procedure can be found in the literature (Ozkan and Yekeler, 2001; Partridge and Smith, 1971).

\section{Results}

\subsection{Turbidity measurements}

The turbidity of potassium lauryl phosphate solution as a function of concentration is shown in Fig. 1. It is evident that the collector is soluble 
at concentrations of less than $1 \times 10^{-4} \mathrm{M}$. Flotation experiments were conducted below this concentration.

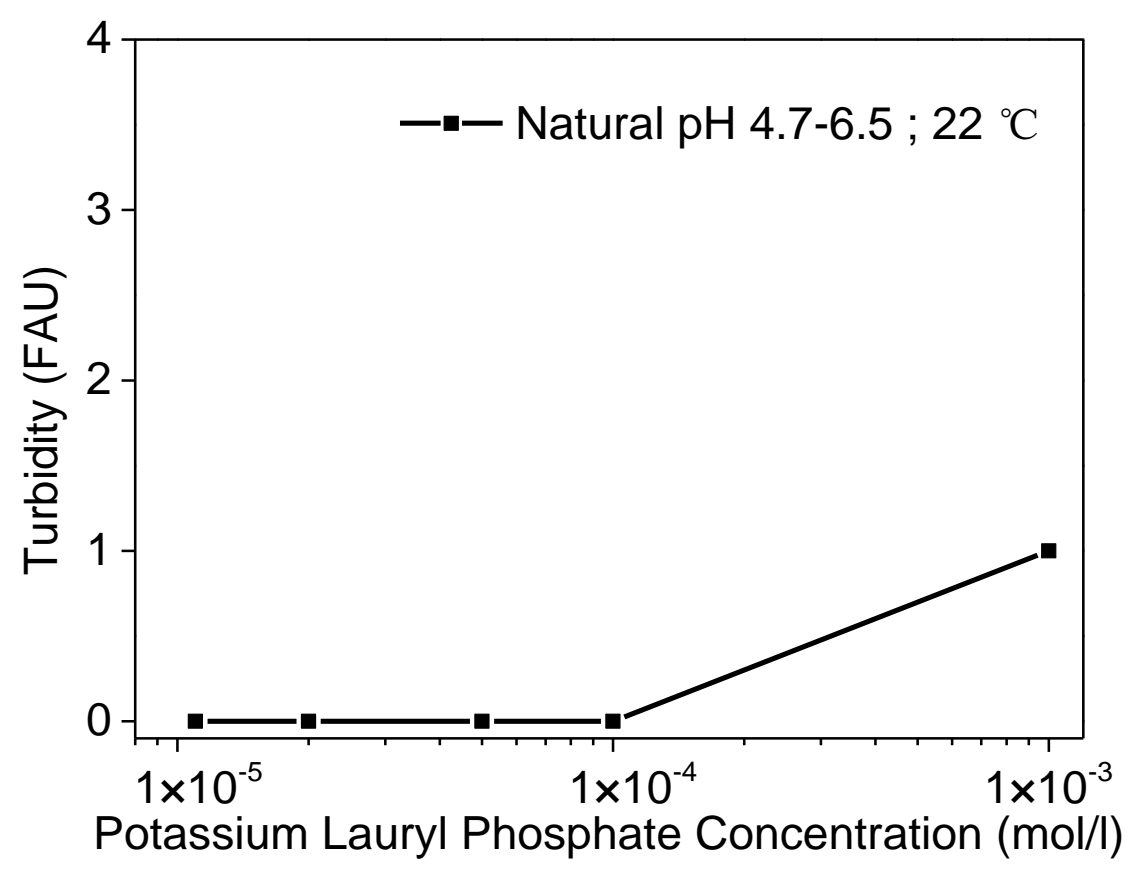

Fig. 1 The turbidity of potassium lauryl phosphate solution as a function of concentration.

\subsection{Distribution of species in solution}

The acid dissociation constant $\left(\mathrm{pK}_{\mathrm{a}}\right)$ is a quantitative measure of the strength of an acid in solution. Each acid has a different $\mathrm{pK}_{\mathrm{a}}$, knowledge of which is essential for understanding solution behavior. Further understanding of the acid dissociation constant $\left(\mathrm{pK}_{\mathrm{a}}\right)$ with respect to solution $\mathrm{pH}$, and its method of determination, can be found in the literature (Reijenga et al., 2013). 
Potassium lauryl phosphate $\left(\mathrm{C}_{12} \mathrm{H}_{26} \mathrm{O}_{4} \mathrm{PK}\right)$ is a salt comprised of one potassium ion and hydrogen ion, and the acid mono alkyl phosphate (denoted as $\mathrm{ROPO}_{3}{ }^{2-}$, where $\mathrm{R}$ corresponds to $\mathrm{C}_{12} \mathrm{H}_{25}$ ). When $\mathrm{C}_{12} \mathrm{H}_{26} \mathrm{O}_{4} \mathrm{PK}$ is dissolved in pure water, there are two equations involved, the measured $\mathrm{pK}_{\mathrm{a}}$ values from this current research are 2.85 and 7.35.

$$
\begin{array}{ll}
\mathrm{ROPO}(\mathrm{OH})_{2}+\mathrm{OH}^{-} \rightleftarrows \mathrm{ROPO}(\mathrm{OH}) \mathrm{O}^{-}+\mathrm{H}_{2} \mathrm{O} & \mathrm{pK}_{1}=2.85 \\
\mathrm{ROPO}(\mathrm{OH}) \mathrm{O}^{-}+\mathrm{OH}^{-} \gtrless \mathrm{ROPO}_{3}{ }^{2-}+\mathrm{H}_{2} \mathrm{O} & \mathrm{pK}_{2}=7.35
\end{array}
$$

The $\mathrm{ROPO}(\mathrm{OH})_{2}$ species is more hydrophobic and lower in solubility than the $\mathrm{ROPO}(\mathrm{OH}) \mathrm{O}^{-}$and $\mathrm{ROPO}_{3}{ }^{2-}$ species, suggesting that this species may be quickly adsorbed at the air/water interface and can form an aggregate in solution more easily (Nakayama et al., 2004). 


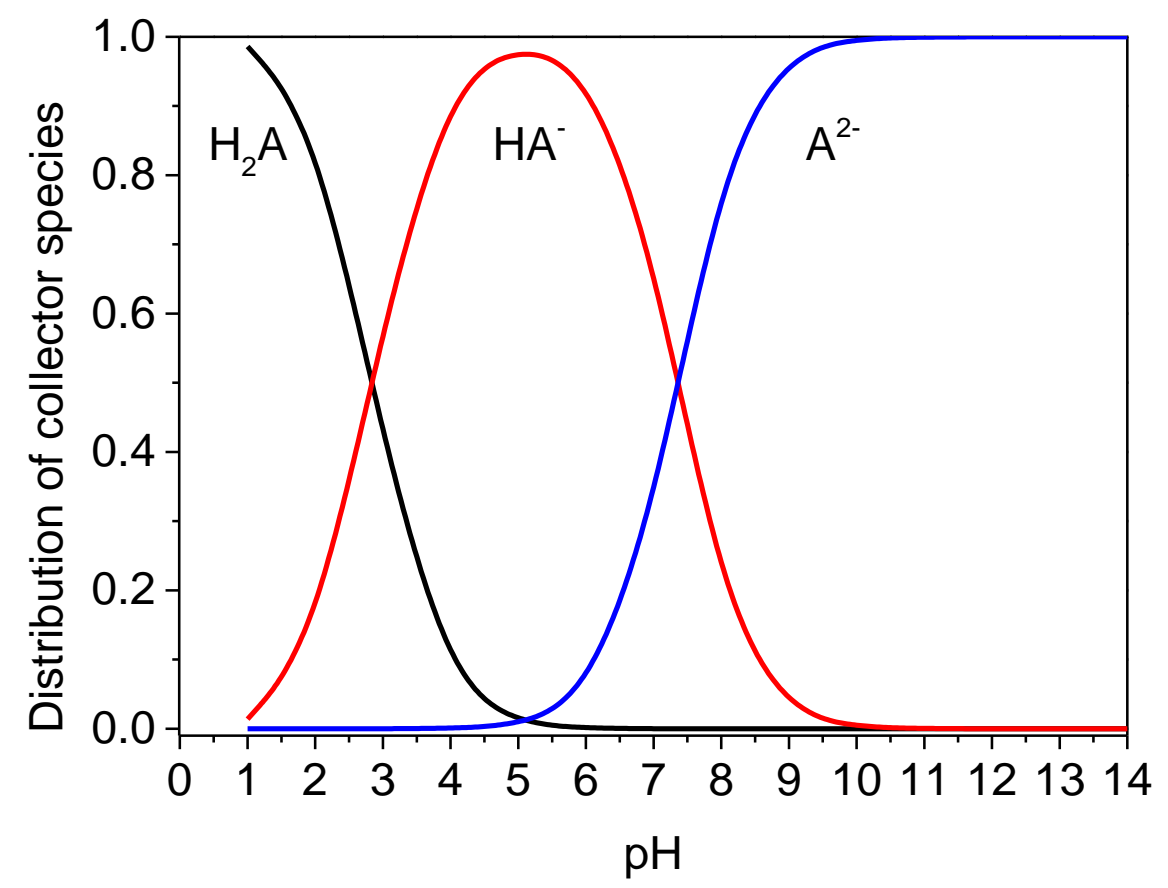

Fig. 2 Distribution of potassium lauryl phosphate species, $\mathrm{H}_{2} \mathrm{~A}, \mathrm{HA}^{-}$, and $\mathrm{A}^{2-}$ in pure water.

The distribution of potassium lauryl phosphate $\left(\mathrm{C}_{12} \mathrm{H}_{26} \mathrm{O}_{4} \mathrm{PK}\right)$ species in solution is shown in Fig. 2 where the $\mathrm{ROPO}_{3}{ }^{2-}$ species is designated by $\mathrm{A}$. It's evident that $\mathrm{HA}^{-}$is the dominate species within the $\mathrm{pH}$ range from 4 to 6 . The first dissociation of the acid form of lauryl phosphate, according to equation (2), begins at a solution $\mathrm{pH}$ of about 1 and is almost complete at $\mathrm{pH} 5$. As the concentration is raised to a higher $\mathrm{pH}$, the second dissociation according to equation (3) begins at a $\mathrm{pH}$ of about 5 and is almost complete at a $\mathrm{pH}$ of 10 . 


\subsection{Contact angle and surface tension measurements}

From Fig. 3, it can be concluded that the $\mathrm{pH}$ value of the potassium lauryl phosphate solution rises steadily in the acidic region from $\mathrm{pH} 4.7$ to $\mathrm{pH} 6.5$ as the concentration increased from $1 \times 10^{-7} \mathrm{M}$ to $1 \times 10^{-4} \mathrm{M}$.

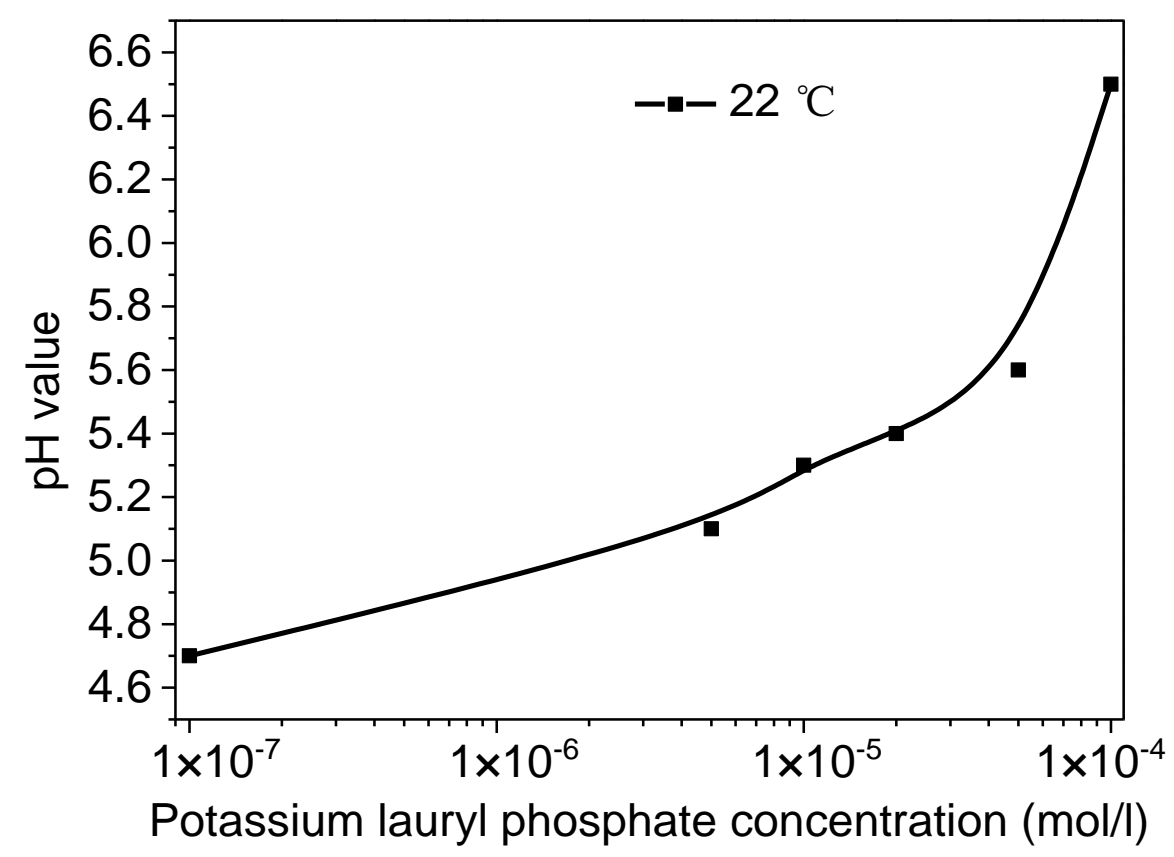

Fig. 3 The $\mathrm{pH}$ value of potassium lauryl phosphate solution as a function of concentration. 


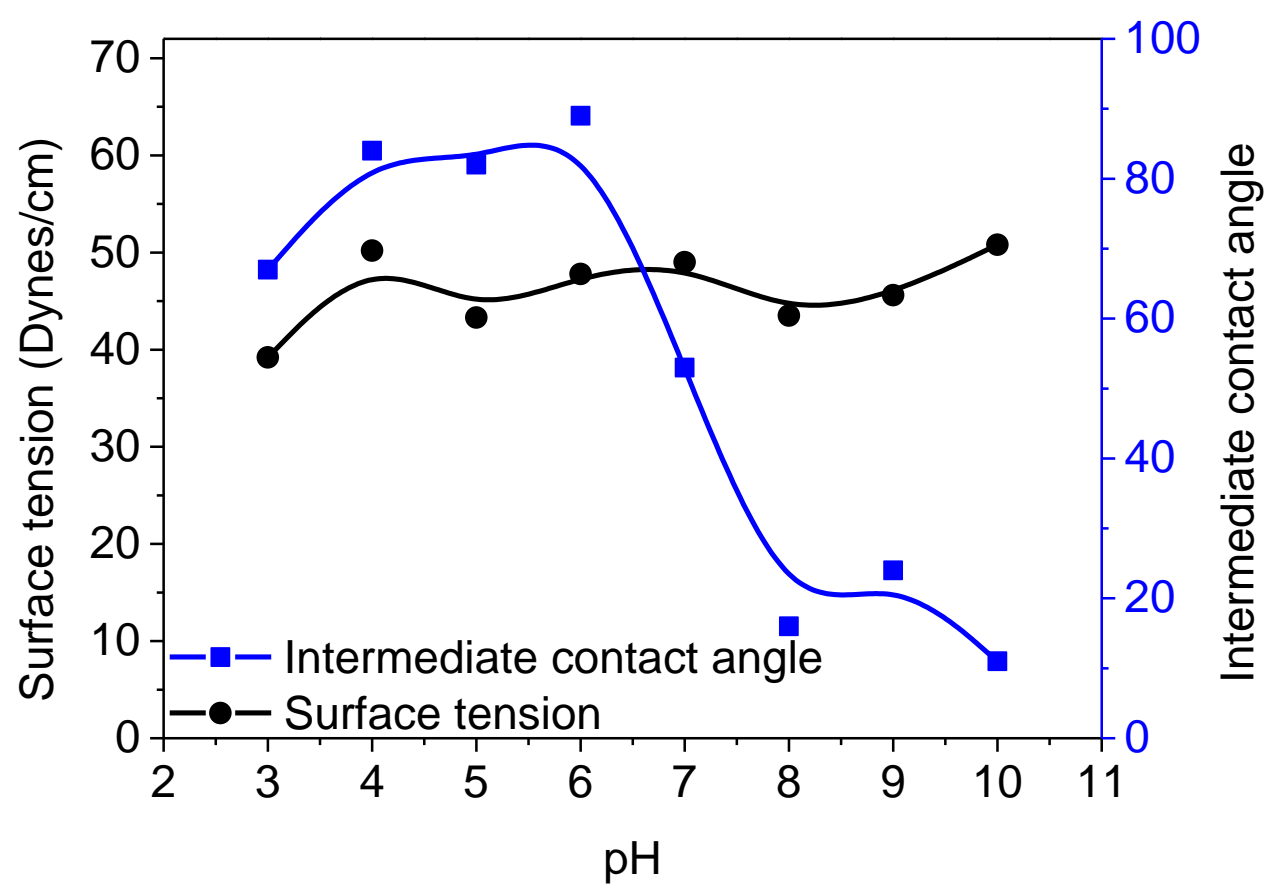

Fig. 4 The intermediate contact angle of bastnaesite and surface tension as a function of $\mathrm{pH}$ for $1 \times 10^{-4} \mathrm{M}$ potassium lauryl phosphate solution; $22 \mathrm{C}^{\circ}$.

It is evident from Fig. 4 that when the $\mathrm{pH}$ is greater than $\mathrm{pH} 6.5$, the contact angle of bastnaesite is reduced, which indicates that the bastnaesite surface changes from a hydrophobic surface state to a hydrophilic surface state as the $\mathrm{pH}$ is increased. Since the $\mathrm{pK}_{1}$ of lauryl phosphate acid is 2.85 , formation of molecular aggregates is expected in the acidic $\mathrm{pH}$ region but less so in the alkaline $\mathrm{pH}$ region. Therefore, the contact angle of bastnaesite might be expected to be larger in the acid region than in the alkaline region. Further research is needed to examine surface spectroscopic features as a function of $\mathrm{pH}$.

An intermediate contact angle of about $80^{\circ}$ for bastnaesite in $1 \times 10^{-4} \mathrm{M}$ potassium lauryl phosphate was found from $\mathrm{pH} 4.0-6.5$, and 
the surface tension fluctuated between $40-50$ dynes $/ \mathrm{cm}$ as a function of $\mathrm{pH}$, which showed that $\mathrm{pH}$ did not affect the surface tension of the potassium lauryl phosphate solution. We know that at a potassium lauryl phosphate concentration of less than $1 \times 10^{-4} \mathrm{M}$ the natural $\mathrm{pH}$ was less than $\mathrm{pH}$ 7, as shown in Fig. 3. Therefore the natural $\mathrm{pH}$ was selected for subsequent experiments.

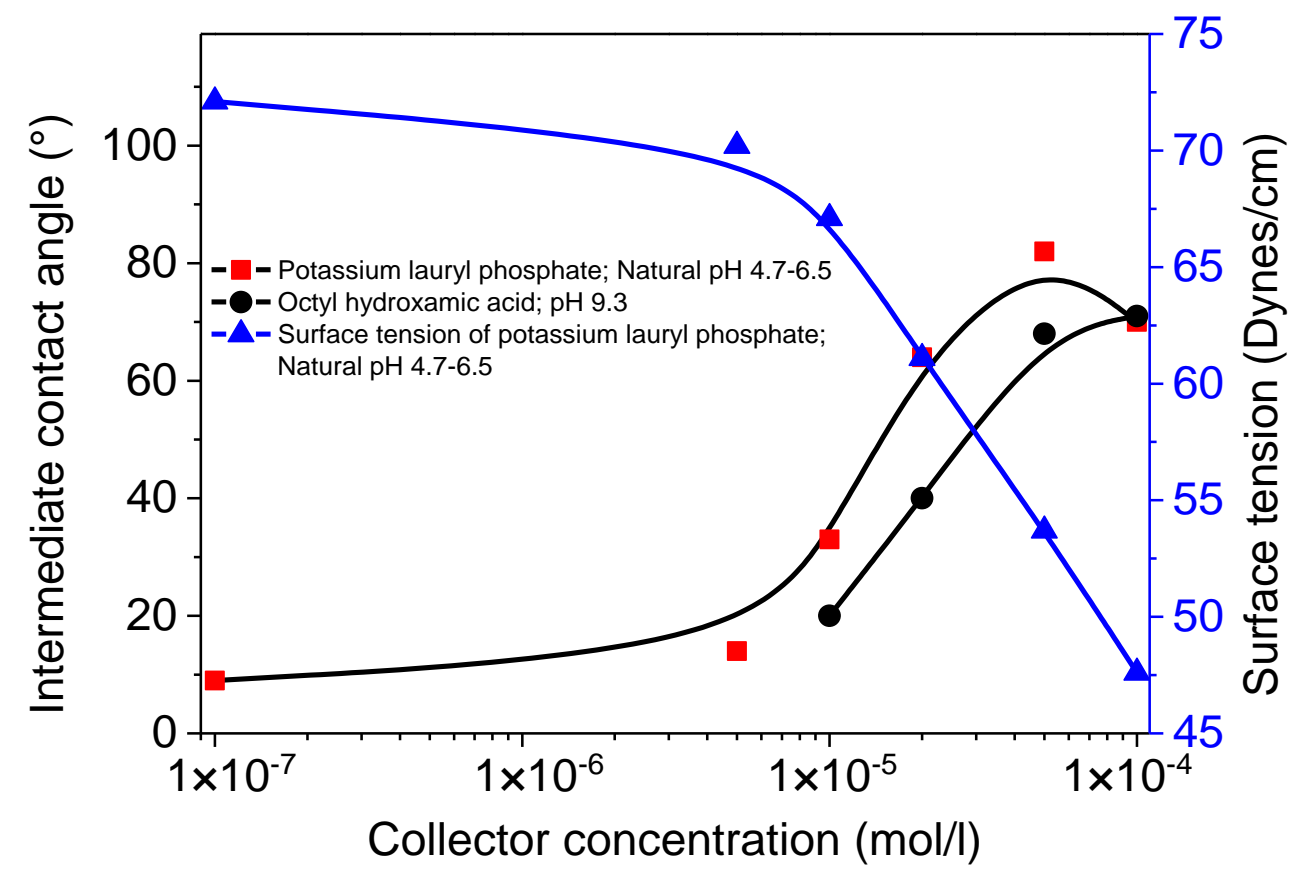

Fig. 5 The intermediate contact angle comparison between potassium lauryl phosphate and octyl hydroxamic acid at a bastnaesite surface. Also included is potassium lauryl phosphate's surface tension as a function of concentration.

In Fig. 5 a contact angle comparison between potassium lauryl phosphate at $\mathrm{pH}$ 4.7-6.5 and octyl hydroxamic acid (Zhang, 2014) at $\mathrm{pH}$ 9.3 is presented. The surface tension of potassium lauryl phosphate is also shown as a function of concentration. The surface tension of potassium 
lauryl phosphate solution decreased from 72 dynes $/ \mathrm{cm}$ at $1 \times 10^{-7} \mathrm{M}$ to about 47 dynes $/ \mathrm{cm}$ at $1 \times 10^{-4} \mathrm{M}$, which was the same trend as reported for the surface tension of SM15 ( an ester of phosphoric acid) as a function of concentration (Srinivas et al., 2004). The results also indicate a substantial reduction in the air/water interfacial tension for solutions having higher concentration $\left(\geq 1 \times 10^{-5} \mathrm{M}\right)$ of potassium lauryl phosphate. This could be one of the contributing factors for improved contact angle results obtained at higher concentrations, since a favorable air/water interfacial tension is required for good flotation (Srinivas et al., 2004).

The intermediate contact angle increased from a mere $33^{\circ}$ to $>60^{\circ}$ when the potassium lauryl phosphate concentration was $\geqslant 1 \times 10^{-5} \mathrm{M}$. Furthermore, and most importantly, it is evident that the potassium lauryl phosphate has a high contact angle of more than $60^{\circ}$ at a low concentration when compared to octyl hydroxamic acid.

\subsection{Zeta potential of bastnaesite}

Zeta potential is the electric potential for the interfacial double layer at the location of the slipping plane relative to a point in the bulk solution away from the interface (Fuerstenau, 1982; Jordens et al., 2014). The pH value where the zeta potential is zero, the isoelectric point (IEP), is an 
important mineral property that can be used to characterize charging of the mineral surface (Pope and Sutton, 1973).

The IEP values for bastnaesite reported in the literature are included in Table 1.The IEP values vary from $\mathrm{pH} 4.6$ to $\mathrm{pH} 9.25$, which might be due to different levels of purity, experimental procedures, solution, etc.

Table 1 IEP values for bastnaesite.

\begin{tabular}{|c|c|c|c|}
\hline IEP & $\begin{array}{l}\text { Purity of } \\
\text { samples }\end{array}$ & Bastnaesite source & Reference \\
\hline $\begin{array}{l}\mathrm{pH} 4.6(2 \mathrm{~h} \mathrm{ag} \\
\text { ing in water) } \\
\text { pH } 4.7\end{array}$ & - & $\begin{array}{c}\text { Mountain Pass, USA } \\
\text { Vietnam }\end{array}$ & $\begin{array}{c}\text { (Smith and } \\
\text { Shonnard, 1986), } \\
\text { (Kim et al., 2010) }\end{array}$ \\
\hline pH 4.9 & $\begin{array}{c}45.3 \% \\
\mathrm{RE}_{2} \mathrm{O}_{3}, 15 \% \mathrm{Fe} \\
12 \% \mathrm{SiO}_{2} \text { and } \\
10 \% \mathrm{Al}_{2} \mathrm{O}_{3}\end{array}$ & Brazil & $\begin{array}{l}\text { (Pavez et al., } \\
\text { 1996) }\end{array}$ \\
\hline pH 6.3 & & Mountain Pass, USA & $\begin{array}{l}\text { (Jordens et al., } \\
\text { 2014) }\end{array}$ \\
\hline $\begin{array}{c}\mathrm{pH} 5.3(<30 \\
\mathrm{min}), 6.8(2 \mathrm{~h}), 7.2(24 \\
\mathrm{h}) \text { ageing in water }\end{array}$ & - & Mountain Pass, USA & $\begin{array}{l}\text { (Robert Houot, } \\
\text { 1991) }\end{array}$ \\
\hline pH 7.0 & - & Baiyan Obo, China & $\begin{array}{l}\text { (Luo and Chen, } \\
1984 \text { ) }\end{array}$ \\
\hline pH 7.8 & $96.5 \%$ pure & $\begin{array}{l}\text { Haoniuping mine, } \\
\text { China }\end{array}$ & (Ren et al., 2000) \\
\hline pH 7.8 & $100 \%$ pure & $\begin{array}{r}\text { Synthetic } \\
\text { Ce-bastnaesite }\end{array}$ & $(\mathrm{Li}, 1982)$ \\
\hline pH 8.0 & $98.1 \%$ pure & $\begin{array}{l}\text { Maoniuping mine, } \\
\text { Sichuan, China }\end{array}$ & (Ren et al., 1997) \\
\hline pH 8.1 & - & $\begin{array}{l}\text { Zagi Mountain, } \\
\text { Pakistan }\end{array}$ & (Zhang, 2014) \\
\hline pH 9.25 & $\begin{array}{r}57.4 \% \mathrm{REO} \\
8.8 \% \mathrm{BaO}, 1.6 \% \\
\mathrm{CaO} \text { and } 0.4 \% \mathrm{SrO}\end{array}$ & Mountain Pass, USA & (Pradip, 1981) \\
\hline
\end{tabular}




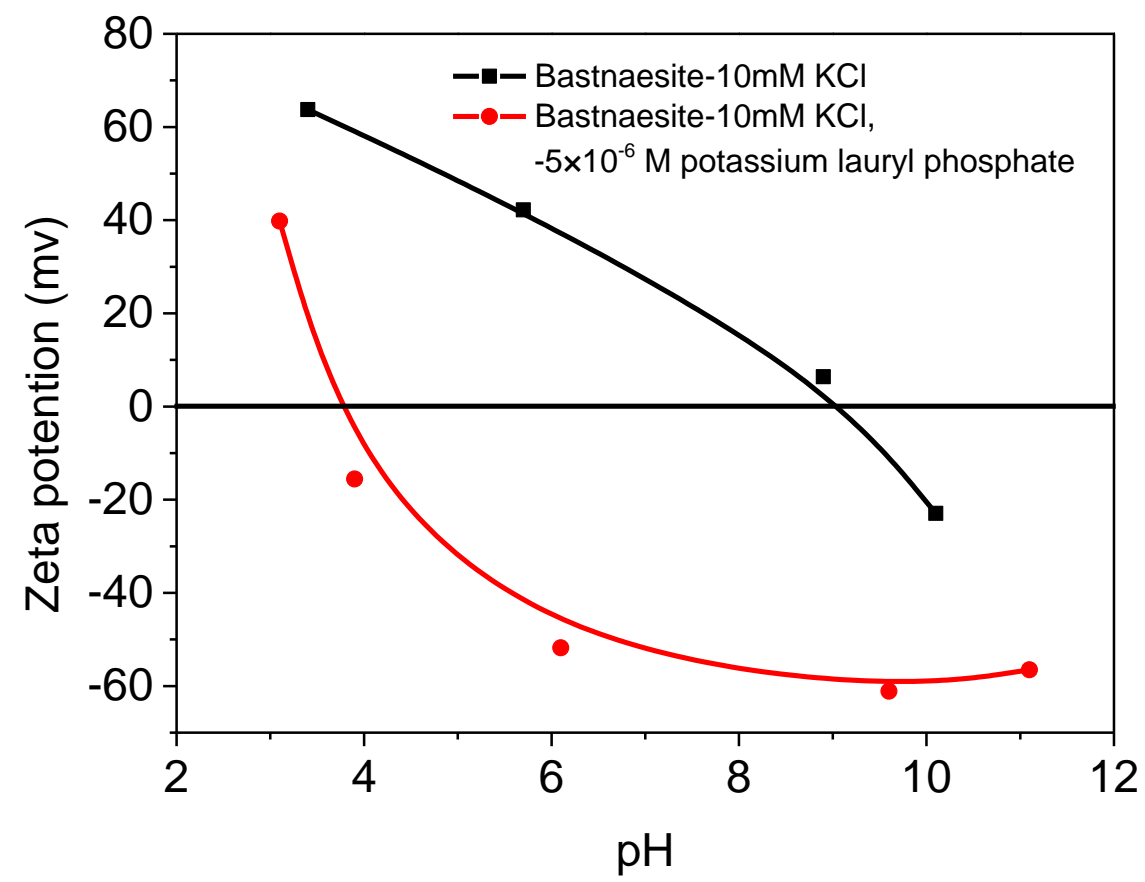

Fig. 6 Zeta potential of bastnaesite in $10 \mathrm{mM} \mathrm{KCl}$ solution, and in $10 \mathrm{mM} \mathrm{KCl}$ with $5 \times 10^{-6} \mathrm{M}$ potassium lauryl phosphate solution as a function of $\mathrm{pH}$.

As shown in Fig. 6, the IEP value of bastnaesite in this study was found to be $\mathrm{pH} 9.0$, and the addition of $5 \times 10^{-6} \mathrm{M}$ potassium lauryl phosphate reduced the IEP value to $\mathrm{pH}$ 3.7. This fact suggests that the lauryl phosphate anion is strongly adsorbed at the bastnaesite surface which accounts for charge reversal and the more negative zeta potential even at the low lauryl phosphate concentration of $5 \times 10^{-6} \mathrm{M}$.

\subsection{Micro-flotation results}

Excellent flotation was achieved at low potassium lauryl phosphate concentrations in the acidic $\mathrm{pH}$ region, see Fig. 7. These results were in 
accord with the contact angle results presented in Fig 4. The dominant collector species from $\mathrm{pH} 4-6$ is the protonated lauryl phosphate anion $\left(\mathrm{HA}^{-}\right)$which suggests that $\mathrm{HA}^{-}$is the effective species reacting with the bastnaesite surface. Further research to determine the adsorption characteristics and to examine surface spectroscopic features is needed.

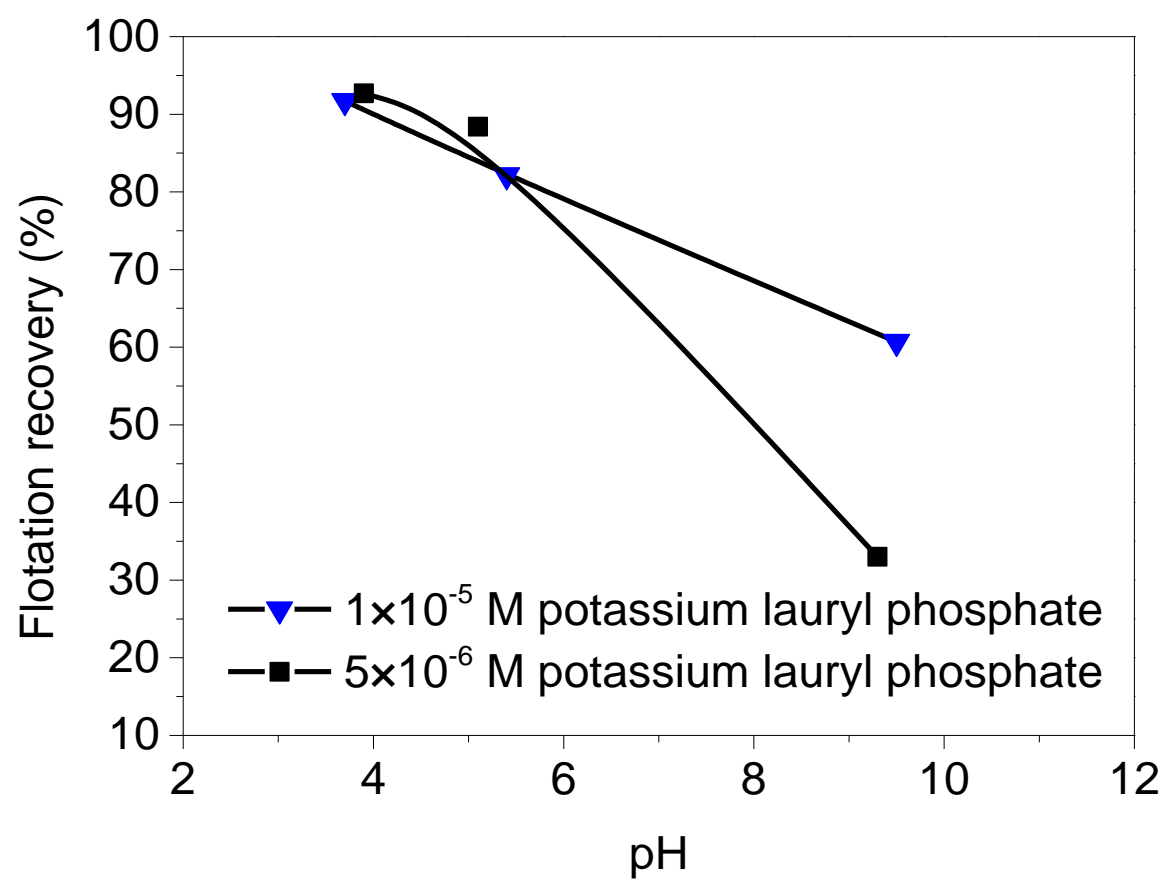

Fig. 7 Bastnaesite flotation with potassium lauryl phosphate collector as a function of $\mathrm{pH}$. 


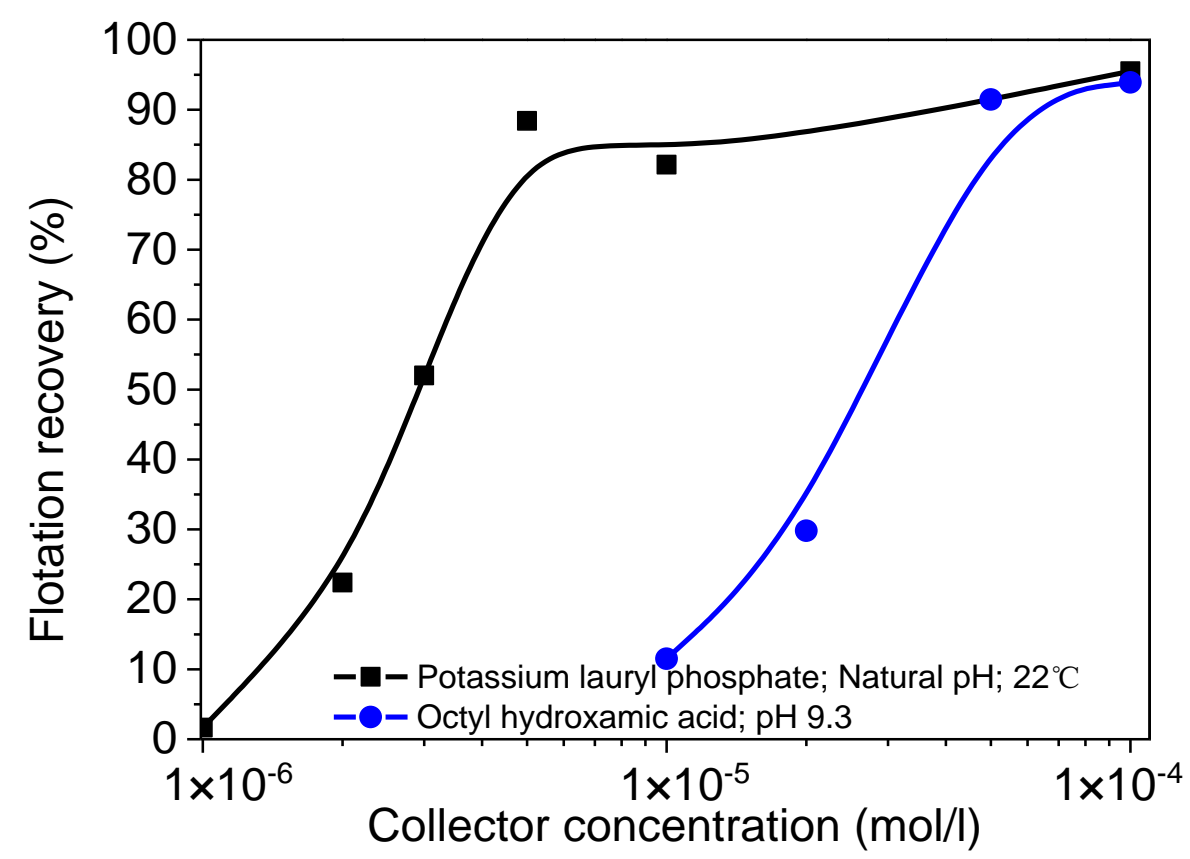

Fig. 8 Micro-flotation recovery comparison between potassium lauryl phosphate solution and hydroxamic acid solution as a function of concentration.

The micro-flotation results for bastnaesite with both potassium lauryl phosphate and octyl hydroxamic acid are presented in Fig.8. The data illustrate important results showing that excellent flotation of bastnaesite is achieved at low lauryl phosphate concentration $\left(5 \times 10^{-6} \mathrm{M}\right)$, when compared with octyl hydroxamic acid. The results clearly indicate that flotation with hydroxamate at $\mathrm{pH} 9.3$ requires ten times the concentration needed for lauryl phosphate flotation in accordance with the captive bubble contact angle results in the literature (Zhang, 2014). 


\section{Discussion}

Limited results from fundamental research are reported in the literature. For example, analysis of the infrared spectra indicates that adsorption of the di-2-EHPA (di-2-ethyl-hexylphosphoric acid) acid dimer $\left(1235 \mathrm{~cm}^{-1}\right)$ occurs at $\mathrm{pH} 4.0$ (Polkin et al., 1973) on the surface of cassiterite. In addition, Srinivas et al. (2004) suggest that a molecular form of the alkyl phosphate collector precipitated as aggregates at the wolframite surface and might be the surface-active species responsible for flotation. Further research is needed to establish the adsorption state of lauryl phosphate at the surface of bastnaesite.

The flotation results for bastnaesite with hydroxamic acid do not agree exactly with previous Hallimond tube flotation tests for bastnaesite (Pradip, 1981) in which case complete bastnaesite recovery was only possible at a higher hydroxamate concentration $\left(>4 \times 10^{-4} \mathrm{M}\right)$. The difference between these results may be due to the apparatus used for the micro-flotation tests, the hydroxamate, and/or the bastnaesite sample. The potassium lauryl phosphate collector provided a better flotation response when compared with octyl hydroxamate, especially at low concentration $\left(<5 \times 10^{-5} \mathrm{M}\right)$. The flotation results for bastnaesite with potassium lauryl phosphate agree very well with previous results on bastnaesite flotation (Jordens et al., 2014), which results also indicate that SM15 (an ester of 
phosphoric acid) is a strong collector for bastnaesite.

As demonstrated in the literature (Pradip, 1981), octyl hydroxamate chemisorbs at the bastnaesite surface due to the stability of the RE hydroxamate salts such as Ce and La hydroxamate. In this regard it is expected that the good flotation of bastnaesite at low levels of lauryl phosphate concentration reflects an even stronger chemisorption potential and preliminary thermodynamic considerations confirm this expectation. The high stability of Ce, La lauryl phosphate, and the corresponding chemisorption reaction at the bastnaesite surface seem to account for flotation at such low levels of collector addition.

\section{Conclusions}

Potassium lauryl phosphate has been used as a collector for bastnaesite for the first time. Experimental results from captive bubble contact angle measurements and micro-flotation experiments showed that potassium lauryl phosphate is a promising collector for bastnaesite with complete recovery for a collector addition of $5 \times 10^{-6} \mathrm{M}$ at $\mathrm{pH}$ 5.1. These results were compared to results for octyl hydroxamate collector as reported in the literature and suggest that potassium lauryl phosphate may be better for bastnaesite flotation. Further research is in progress. 
Conclusions at this time include the following points:

1. Captive bubble contact angle measurements of more than $60^{\circ}$ for bastnaesite at $\mathrm{pH}$ 4.7-6.5 with potassium lauryl phosphate at a low concentration $\left(\leq 5 \times 10^{-5} \mathrm{M}\right)$ suggest that potassium lauryl phosphate might be a better collector for bastnaesite than octyl hydroxamate. Under these conditions the lauryl phosphate anion is protonated and the bastnaesite is positively charged at $\mathrm{pH}$ 4.7-6.5 prior to collector adsorption.

2. Results from micro-flotation experiments with a high quality bastnaesite sample confirmed the expectation established from contact angle measurements. Complete flotation recovery of bastnaesite was achieved with a potassium lauryl phosphate concentration of $5 \times 10^{-6} \mathrm{M}$ at pH 5.1.

3. Electrophoretic mobility measurements suggest strong adsorption of lauryl phosphate at the bastnaesite surface with the zeta potential at $\mathrm{pH}$ 6 changing from about $+40 \mathrm{mv}$ to $-50 \mathrm{mv}$ with the addition of $5 \times 10^{-6} \mathrm{M}$ lauryl phosphate. 


\section{Acknowledgements}

Funding for this research by the Division of Chemical Sciences, Geosciences, and Biosciences, Office of Basic Energy Sciences of the U.S. Department of Energy through Grant No. DE-FG03-93ER14315 is gratefully acknowledged. Weiping's fellowship was provided by the China Scholarship Council (No.201306370139). The authors would like to thank Prof. Hui Xu and Dr. Xia Zhang for their help, and Ms. Dorrie Spurlock for her assistance with the preparation of the manuscript.

\section{References}

Babić, S., Horvat, A.J.M., Mutavdžić Pavlović, D., Kaštelan-Macan, M., 2007. Determination of pKa values of active pharmaceutical ingredients. TrAC Trends in Analytical Chemistry 26, 1043-1061.

Bulatovic, S.M., 2010. Flotation of REO minerals, in: Handbook of Flotation Reagents: Chemistry, Theory and Practice: Flotation of Gold, PGM and Oxide Minerals, first ed. Elsevier Science, Amsterdam, NL, pp. 151-173.

Chehreh Chelgani, S., Hart, B., Xia, L., 2013. A TOF-SIMS surface chemical analytical study of rare earth element minerals from micro-flotation tests products. Minerals Engineering 45, 32-40.

Drelich, J., Chibowski, E., Meng, D.D., Terpilowski, K., 2011. Hydrophilic and superhydrophilic surfaces and materials. Soft Matter 7, 9804-9828.

Drelich, J., Miller, J.D., Good, R.J., 1996a. The effect of drop (bubble) size on advancing and receding contact angles for heterogeneous and rough solid surfaces as observed with sessile-drop and captive-bubble techniques. Journal of Colloid and Interface Science 179, 37-50.

Drelich, J., Wilbur, J.L., Miller, J.D., Whitesides, G.M., 1996b. Contact angles for liquid drops at a model heterogeneous surface consisting of alternating and parallel hydrophobic/hydrophilic strips. Langmuir 12, 1913-1922.

Fuerstenau, D.W., 1982. Mineral-water interfaces and the electrical double layer, in: King, R.P. (Ed.), Principles of Flotation. South African Institute of Mining and Metallurgy, Johannesburg, SA, pp. 17-30.

Fuerstenau, D.W., Pradip, 1988. Alkyl hydroxamates as collectors for the flotation of bastnaesite rare-earth ores, in: Bautista, R.G., Wong, M.M. (Eds.) Rare Earths, Exraction, Preparation and Applications, The Minerals, Metals and Materials Society, Warrendale, PA, USA, pp. 57-70. 
Greenwood, R., 2003. Review of the measurement of zeta potentials in concentrated aqueous suspensions using electroacoustics. Advances in Colloid and Interface Science 106, 55-81.Goncharuk, V.V., Terletskaya, A.V., Terletskii, O.V., Bogoslovskaya, T.A., Pashuta, A.S., 2009. Portable laboratory Akva-Test designed for the drinking water analysis in the field environment. Journal of Water Chemistry and Technology 31, 195-200.

Houot, R., Cuif, J.-P., Mottot, Y., Samama, J.C., 1991. Recovery of rare earth minerals, with emphasis on flotation process. Materials Science Forum 70-72, 301-304.

Hunter, R.J., 1998. Recent developments in the electroacoustic characterisation of colloidal suspensions and emulsions. Colloids and Surfaces A: Physicochemical and Engineering Aspects 141, 37-65.

Jordens, A., Cheng, Y.P., Waters, K.E., 2013. A review of the beneficiation of rare earth element bearing minerals. Minerals Engineering 41, 97-114.

Jordens, A., Marion, C., Kuzmina, O., Waters, K.E., 2014. Surface chemistry considerations in the flotation of bastnäsite. Minerals Engineering 66-68, 119-129.

Kim, J., Dodbiba, G., Fujita, T., Fujii, N., 2010. Characteristics analysis of a bastnaesite rare earth mineral for recovery of cerium. in: XXI International Mineral Processing Congress (IMPC), 2927-2932.

Lam, C.N.C., Ko, R.H.Y., Yu, L.M.Y., Ng, A., Li, D., Hair, M.L., Neumann, A.W., 2001. Dynamic cycling contact angle measurements: Study of advancing and receding contact angles. Journal of Colloid and Interface Science 243, 208-218.

Lam, C.N.C., Wu, R., Li, D., Hair, M.L., Neumann, A.W., 2002. Study of the advancing and receding contact angles: liquid sorption as a cause of contact angle hysteresis. Advances in Colloid and Interface Science 96, 169-191.

Li, C., 1982. Solubility and electrokinetic behavior of synthetic bastnaesite. M.S. Thesis, University of California, Berkeley, USA.

Luo, J., Chen, X., 1984. Research into the recovery of high-grade rare-earth concentrate from Baotou Complex iron ores, China. Mineral Processing and Extractive Metallurgy, 663-675.

Nagaraj, D., 1988. The chemistry and application of chelating or complexing agents in minerals separations. in: Reagents in Mineral Technology, Marcel Dekker, Inc., pp. 257-334.

Nakayama, K., Tari, I., Sakai, M., Murata, Y., Sugihara, G., 2004. Aggregation behavior of sodium mono-n-dodecyl phosphate surfactant in aqueous media, and function in catalytic activity. I.Multi-step aggregates formation and catalytic activity for hydrolysis of p-nitrophenyl acetate in aqueous solution. Journal of Oleo Science 53, 247-265.

Onweluzo, J., Akuagbazie, C., 2010. Assessment of the quality of bottled and sachet water sold in Nsukka town. Agro-science Journal Tropical Agriculture Food Environment and Extension 9, 104-110. Ozkan, A., Yekeler, M., 2001. A new microscale flotation cell: Combination of Canadian column and Partridge-Smith cell, in: Proceedings of the Seventeenth International Mining Congress and Exhibition of Turkey, Ankara, TURKEY, pp. 759-763.

Partridge, A., Smith, G., 1971. Small-sample flotation testing: a new cell. Transactions Institute of Mining and Metallurgy, Sect. C 80, C199.

Pavez, O., Brandao, P., Peres, A., 1996. Adsorption of oleate and octyl-hydroxamate on to rare-earths minerals. Minerals Engineering 9, 357-366.

Polkin, S.I., Laptev, S.F., Matsuev, L.P., Adamov, E.V., Krasnukhina, A.V., Purvinskii, O.F., 1973. Theory and practice in the flotation of cassiterite fines, in: Jones, M.J. (Ed.), Proceedings 10th 
International Minerals Processing Congress, Institute Mining and Metallurgy, London, UK, pp. 593-629.

Pope, M.I., Sutton, D.I., 1973. The correlation between froth flotation response and collector adsorption from aqueous solution. Part I. Titanium dioxide and ferric oxide conditioned in oleate solutions. Powder Technology 7, 271-279.

Pradip, 1981. The surface properties and flotation of rare-earth minerals. Ph.D. Thesis, University of California, Berkeley, CA, USA, p. 222.

Pradip, Fuerstenau, D.W., 1985. Adsorption of hydroxamate collectors on semisoluble minerals Part II: Effect of temperature on adsorption. Colloids and Surfaces 15, 137-146.

Reijenga, J., van Hoof, A., van Loon, A., Teunissen, B., 2013. Development of methods for the determination of pKa values. Analytical Chemistry Insights 8, 53-71.

Ren, J., Lu, S., Song, S., Niu, J., 1997. A new collector for rare earth mineral flotation. Minerals Engineering 10, 1395-1404.

Ren, J., Song, S., Lopez-Valdivieso, A., Lu, S., 2000. Selective flotation of bastnaesite from monazite in rare earth concentrates using potassium alum as depressant. International Journal of Mineral Processing 59, 237-245.

Schwer, C., Kenndler, E., 1991. Electrophoresis in fused-silica capillaries: the influence of organic solvents on the electroosmotic velocity and the zeta potential. Analytical Chemistry 63, 1801-1807.

Smith, R.W., Shonnard, D., 1986. Electrokinetic study of the role of modifying agents in flotation of salt-type minerals. AIChE Journal 32, 865-868.

Srinivas, K., Sreenivas, T., Padmanabhan, N., Venugopal, R., 2004. Studies on the application of alkyl phosphoric acid ester in the flotation of wolframite. Mineral Processing \& Extractive Metallurgy Review 25, 253-267.

Zhang, J., Jian, B., 1981. An investigation of rare earth ore flotation using $\alpha$-styrylphosphonic acid. Mining and Metallurgical Engineering 2, 26-30.

Zhang, J., Que, X., Jian, B., 1982. Collecting role of organic phosphoric acids on rare-earths of Weishan. Nonferrous Metals 34, 29-32.

Zhang, X., 2014. Surface chemistry aspects of flourite and bastnaesite flotation systems. Ph.D. Thesis, The University of Utah, Salt Lake City, UT, USA.

Zhang, X., Du, H., Wang, X., Miller, J.D., 2014. Surface chemistry aspects of bastnaesite flotation with octyl hydroxamate. International Journal of Mineral Processing 133, 29-38.

Zhou, G., Luo, J., 1989. Mechanism of flotation using citric acid for separating monazite from bastnaesite. Nonferrous Metals 41, 33-40.

Zhou, G., Luo, J., 1990. Mechanism of flotation using mono-alkyl ester phosphoric acid for bastnaesite. Journal of the Chinese Rare Earth Society 8, 261-264. 